УдК 616.381-089.84-089.27:615.841:615.846/.847.8:615.832.8]-092.9

DOI

( ) В. М. ЛИСЕНКО 1 , М. Ю. КРЕСТЯНОВ

В. В. ПЕРЕКРЕСТ ${ }^{2}$, Д. Д. КУНКІН²

Національна медична академія післядипломної освіти імені П. Л. Шупика МОз України ${ }^{1}$

Національний технічний університет України "Київський політехнічний інститут" МОН України²

КЗ “Ірпінська центральна міська лікарня" ${ }^{3}$ Буча

\title{
Електромагнітні і теплові процеси в перетворювачах при зварюванні очеревини в експерименті
}

\author{
V. M. LYSENKO ${ }^{1}$, M. Y. KRESTIANOV ${ }^{1}$, R. O. BALATSKY ${ }^{1}$, O. A. POTAPOVI ${ }^{3}$, YE. D. DZYUBA ${ }^{2}$, V. V. PEREKREST ${ }^{2}$, \\ D. D. KUNKIN²
}

National Medical Academy of Postgraduate Education by P. L. Shupyk of MPH of Ukraine ${ }^{1}$ National Technical University of Ukraine "Kyiv Polytechnic Institute"2

"Irpin Central City Hospital"3, Bucha

\section{ELECTROMAgnetic AND THERMAL PROGESSES IN WELDING DEVICES DURING PERITONEUM WELDING IN EXPERIMENT}

\begin{abstract}
У статті представлено модель опору біологічної тканини та алгоритм керування перетворювачем для високочастотної електрокоагуляції. Розглянуто особливості побудови моделі процесу нагріву біологічної тканини 3 урахуванням необхідних параметрів та допущень при розрахунках. В експериментальних умовах при зварюванні країв очеревини у кролів була перевірена електрична та теплова модель опору біологічної тканини. Результати є основою для вдосконалення існуючих та створення нових алгоритмів керування вихідною потужністю високочастотного електрохірургічного апарата (ЕХВА). Модель використовували для розробки алгоритму процесу біполярного з'єднання біологічних тканин, який враховує імпеданс тканини і максимальний час електрохірургічного впливу на тканини.

The paper presents a model of biological tissue impedance and algorithm of control for high frequency electrocoagulation converter. The features of model building process of heating of biological tissues is considering the necessary parameters and assumptions in our calculations. Reviewed model is taking into account the necessary parameters and assumptions in the calculations. The team, in experimental conditions, tests electrical resistance and thermal model of biological tissues during the welding of the peritoneum edges in rabbits. These results are the basis for improving existing and for further creating of new algorithms control of power output in high freguency surgical unit (EXBA). Tested model created for the development of the algorithm of process bipolar connection for biological tissues takes into account tissue impedance and maximum time of electrosurgical effects on the tissue.
\end{abstract}

Постановка проблеми і аналіз останніх досліджень та публікацій. Людина використовувала теплову енергію у лікуванні ран, починаючи із неоліту. Досліди B. Franklin та J. Wesley із струмом постійної напруги були підгрунтям для впровадження у хірургічну практику термокаутерів із пасивною передачею тепла до тканин від інструмента. Піонером використання змінного струму в медицині вважається французький фізіолог Arsené D’Arsonval, який називав такий вплив на тканини електрофульгацією. У 1909 році Doyen представив біполярний високочастотний інструмент 3 метою коагуляції. Всесвітньо відомий нейрохірург Harvey W. Cushing вже у 1926 році використовував енергетичну платформу, розроблену William T. Bovie, значно зменшивши інтраопераційну крововтрату. На сьогодні пошук ідеального джерела енергії не тільки не припиняється, а й набирає потужності $[7,8]$.

На своєму шляху хірурги використовували багато інструментів для механічного роз'єднання та відновлення цілісності тканин. Для повсякденної практики в операційній доступно багато енергетичних джерел, що спрямовані на роз’єднання тканин організму та отримання стійкого гемостазу, однак проблема енергетичного з’єднання тканин досі залишається не розкритою та потребує глибокого наукового вивчення.

Існують поодинокі публікації щодо використання лазерної коагуляції для зварювання біологічних тканин [9]. Однак принципи сучасної (доказової) медицини вимагають експериментального обгрунтування процесів зварювання тканин. 
Мета роботи: розробка та експериментальна перевірка електричної та теплової моделі опору біологічної тканини під час зварювання країв очеревини у кролів.

Матеріали і методи. Досліди були проведені на 16 кролях лінії Українська шиншила масою 3,1 - 3,4 кг одного віку, без ознак захворювань, яких утримували у віварії Національної медичної академії післядипломної освіти імені П. Л. Шупика МО3 України, відповідно до загальноприйнятих норм не менше 10 діб перед початком експерименту. Усіх тварин утримували на стандартному раціоні віварію із додаванням спеціалізованого вітамінного препарату “Milch Drops” TM Trixie.

Експериментальну роботу здійснювали із дотриманням загальноприйнятих правил поводження із лабораторними тваринами: “Правила проведення робіт із використанням експериментальних тварин” (Страсбург, 1997 р.), GLP (1981р.), Конвенції Ради Європи про охорону хребетних тварин, які використовуються в експериментах та інших наукових цілях від 18.03.1986, Директиви ЄЕС № 609 від 24.11.1986 р., GCР (1996 р.). Дослідження виконували відповідно до “Загальних етичних принципів експериментів на тваринах”, ухвалених Першим національним конгресом з біоетики (Київ, 2001).

Седацію тварин проводили за допомогою ксилазину гідрохлориду 20 мг/мл із розрахунку на масу тіла. 3 настанням седації переходили до регіонарного знеболюваня. Пальпаторно визначали проміжок L3-L4 та виконували пункцію з пошаровою інфільтрацією 2,0-2,5 мл 2 \% розчину лідокаїну субарахноїдального простору. Через 1-2 хв у тварин перевіряли пателярний рефлекс, у випадку вдалої анестезії рефлекс був негативним. Всі операційні втручання проводили в асептичних умовах із використанням стерильних хірургічних інструментів та перев’язувального матеріалу. Враховуючи критично малу товщину очеревини у кролів, перед іiї дисекцією виконували гідропрепаровування за допомогою інсулінового шприца, вводячи 1-2 мл 0,25 \% розчину бупівакаїну гідрохлориду (лонгокаїну) у 4-х попередньо обраних ділянках черевної стінки. Виконавши гідропрепарування, проводили розсічення очеревини скальпелем довжиною до 2 см, 3 подальшим сепаруванням іï тупим шляхом від передньої черевної стінки. Після цього краї очеревини заварювали адаптованим інструментом у режимі “Коагуляція”.

Результати досліджень та їх обговорення. Одним із прогресивних напрямків високочастотної електрохірургії (ВЧ) є високочастотне з'єднання м'яких тканин, в тому числі очеревини. В Україні над цією проблемою працюють вчені з інституту електрозварювання (IE) ім. Є. О. Патона та науково-дослідного інституту прикладної електроніки (НДІ ПЕ) НТУУ “Київський політехнічний інститут”, практичним впровадженням отриманих результатів - кафедра хірургії та судинної хірургії НМАПО імені П. Л. Шупика.

Для отримання якісного ВЧ-з'єднання або перекриття судин необхідно визначити алгоритм та закон керування високочастотним електрохірургічним апаратом (EXBA), які можуть змінювати рівень вихідної потужності залежно від обраного режиму та сигналів зворотного зв'язку.

Особливістю цих режимів $\epsilon$ :

- нагрівання тканини електричним струмом високої частоти за допомогою спеціальних біполярних інструментів дозволяє отримати з'єднання попередньо розрізаної тканини;

- при нагріванні тканини її імпеданс $Z$ спочатку зменшується і досягає мінімального значення $Z_{\min }$, а потім починається коагуляція білків тканини, що призводить до збільшення імпедансу;

- для успішного ВЧ-з'єднання або перекриття судин необхідно забезпечити стабілізацію імпедансу та температури на етапі коагуляції.

Тому результати досліджень теплових та електромагнітних процесів у тканині при її нагріві ВЧструмом дозволяють створити нові алгоритми та закони керування вихідною напругою ЕХВА для забезпечення якісного ВЧ-з'єднання та перекриття судин.

\section{I. Структурна схема ЕХВА}

У статті розглядається прилад, структурна схема якого зображена на рисунку 1. Даний ЕXBA складається з вхідного модуля, який створює необхідні постійні напруги живлення всіх вузлів.

Постійна напруга регулюється транзисторним регулятором до заданих системою керування параметрів. Потім надходить на вхід ВЧ-інвертора, де перетворюється у змінну необхідної амплітуди. Система керування забезпечує заданий алгоритм роботи пристрою залежно від сигналів зворотного зв'язку. Напруга та струм у навантаженні (сигнали зворотного зв'язку) обчислюються вимірювачем струму та вимірювачем напруги, відповідно, і надходять на вхід системи керування.

Основною відмінністю даного апарата $[2,4,5]$ $\epsilon$ те, що вимірювання напруги та струму відбувається безпосередньо на робочій частині інструмента. Таке рішення дозволяє підвищити точність вимірювання та лінійність.

Вимірювання напруги та струму відбувається з інтегруванням, тобто отриманням середніх значень. 


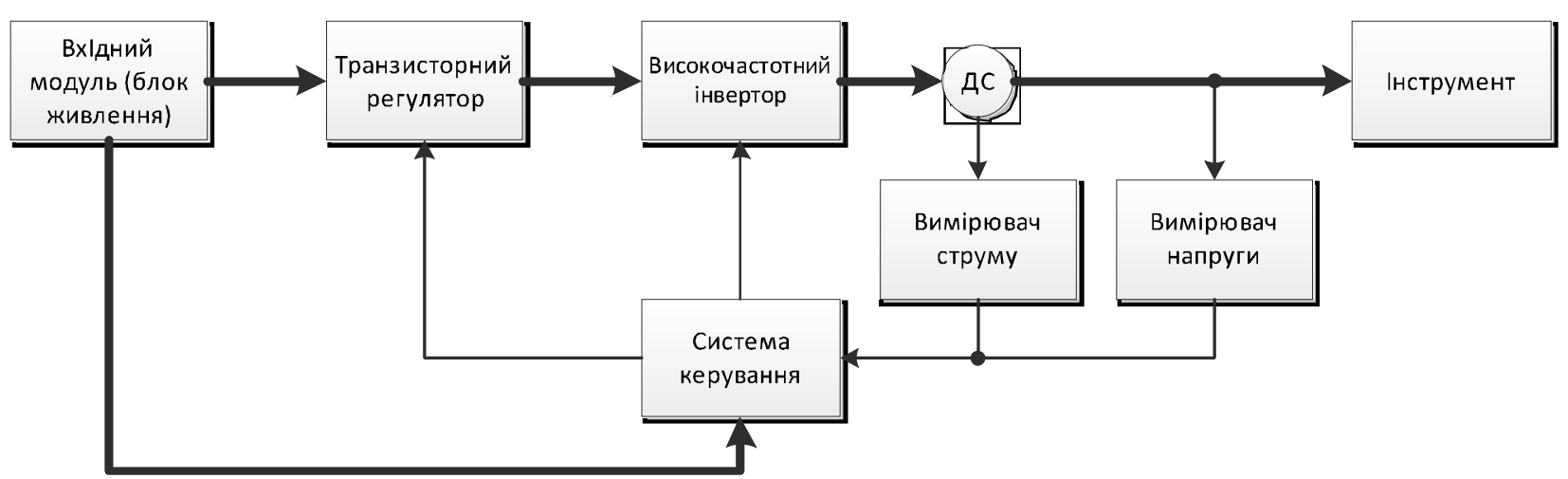

Рис. 1. Структурна схема ЕХВА.

При розрахунку отримується значення модуля імпедансу. Це дає змогу для моделювання використовувати спрощену схему, яка зображена на рисунку 2.

Оскільки активний опір ВЧ-інвертора значно менший, ніж модуль імпедансу тканини, то ним можна знехтувати, а тканину з інструментом та з'єднувальними провідниками замінити еквівалентним нелінійним опором R1.

B [US5472443] (рис. 3) [3] описано експериментальну залежність опору біологічної тканини від її температури. Видно, що її можна апроксимувати такою функцією:

$$
R(T)=\left|-k_{1}\left(T-T_{\text {поч }}\right)^{2}+R_{\text {поч }}\right|-\frac{k_{2} \cdot T}{T_{\min }}+k_{2},
$$

де $R(T)$ - опір тканини, $k_{1}, k_{2}-$ коефіцієнти, які залежать від конкретної тканини, $T$ - температура тканини, $T_{\text {поч }}$ - температура тканини до початку коагуляції, $R_{\text {поч }}-$ опір тканини при початковій температурі, $T_{\min }-$ температура, при якій досягається мінімум опору.

Побудова моделі біологічної тканини та алгоритму керування $€$ технічним рішенням, що дозволяє розробити перетворювач, здатний забезпечи-

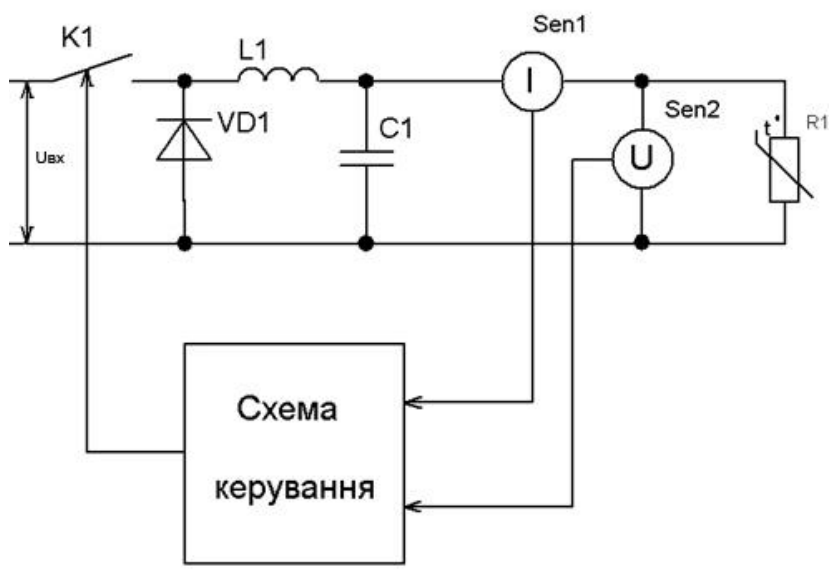

Рис. 2. Спрощена структурна схема ЕХВА. ти якісне з’єднання тканин та повторюваність результатів. Реалізація цього рішення передбачає розв'язання таких завдань:

1) побудова електричної моделі опору біологічної тканини;

2) побудова теплової моделі процесу коагуляції;

3) розробка алгоритму керування потужністю перетворювача;

4) отримання загальних математичних співвідношень, що об'єднують попередньо побудовані моделі;

5) перевірка алгоритму з використанням розроблених моделей у віртуальному середовищі.

II. Електрична та теплова модель опору біологічної тканини

Як модель для розрахунків розглянемо (рис. 4) затиснену між двома браншами інструмента очеревину кроля. 3'єднання очеревини проводили за допомогою електрозварювання. Як джерело енергії використовували ЕКВЗ-300 “Патонмед” та ЕКЗ01М. Для з’єднання країв очеревини кроля використовували спеціальні біполярні пінцети та затискачі.

Електричний струм протікає через тканину між браншами інструмента, що призводить до іiї розі-

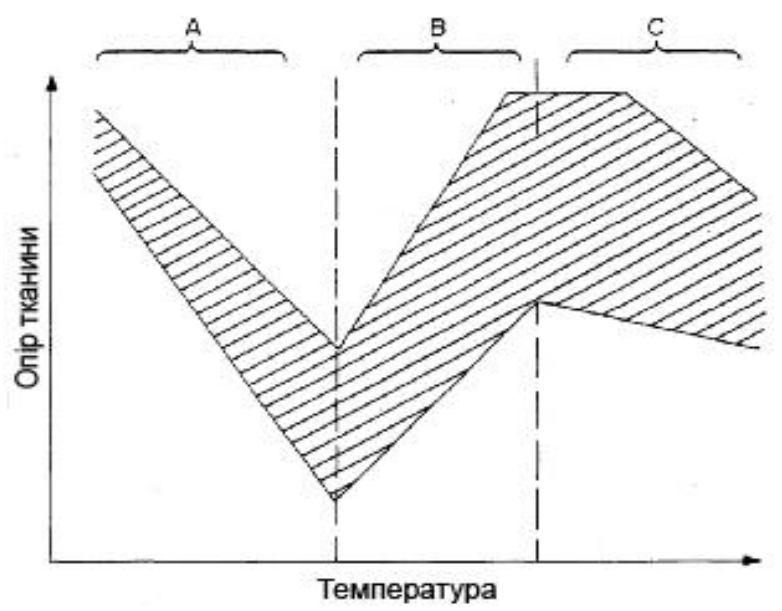

Рис. 3. Експериментальна залежність опору біологічної тканини від їі температури. 


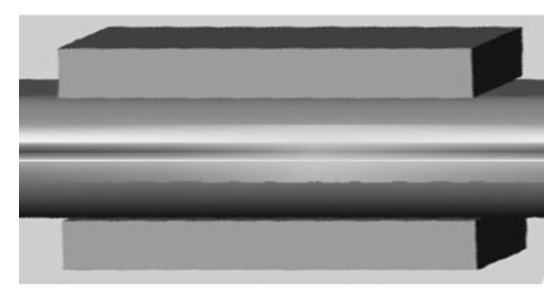

Рис. 4. Модель тканини для розрахунків.

гріву. В найпростішому випадку знехтуємо втратами тепла. Вважатимемо, що все тепло іде на розігрів тканини.

Складемо ітераційну модель розігріву, яка буде описуватися такими рівняннями:

$$
\begin{aligned}
& t_{i+1}=t_{i}+d t \\
& R_{i}=\left|-k_{1}\left(T_{i}-T_{\text {поч }}\right)^{2}+R_{\text {поч }}\right|-\frac{k_{2} \cdot T_{i}}{T_{\min }}+k_{2} \\
& \left.\Delta Q_{i}=\frac{\left(1+\frac{U_{\max }}{R_{\partial t}} R_{i}\right.}{R_{i}} \cdot \begin{array}{c}
d t \\
d t \\
d t
\end{array}\right) d t \\
& T_{i+1}=T_{i}+\frac{\Delta Q_{i}}{c \cdot m},
\end{aligned}
$$

де третє рівняння описує кількість теплоти, що виділяється за період, четверте рівняння - зміну температури за період, $T_{i}$ - температура на $i$ - му інтервалі, $R_{i}$ - опір тканини на $i$ - му інтервалі, $\gamma-$ коефіцієнт заповнення імпульсами, $R_{\partial t}-$ активний опір дроселя регулятора, $U_{\max }-$ напруга на вході регулятора, $d t$ - період модуляції, $\Delta Q_{i}-$ кількість теплоти, що виділилась за $i$-й інтервал, с - теплоємність тканини, $m$ - маса тканини між браншами.

Оскільки на робочій частоті ЕХВА активний опір дроселя значно менший, ніж опір тканини, знехтуємо втратами в дроселі понижуючого імпульсного стабілізатора і отримаємо таку модель:

$$
\begin{aligned}
& t_{i+1}=t_{i}+d t \\
& R_{i}=\left|-k_{1}\left(T_{i}-T_{\text {поч }}\right)^{2}+R_{\text {поч }}\right|-\frac{k_{2} \cdot T_{i}}{T_{\min }}+k_{2} \\
& \Delta Q_{i}=\frac{\left(\gamma \cdot U_{\max }\right)^{2}}{R_{i}} \cdot d t \\
& T_{i+1}=T_{i}+\frac{\Delta Q_{i}}{c \cdot m}
\end{aligned}
$$

\section{III. Результати моделювання}

Розрахунок моделей було проведено в середовищі MATLAB/MATCAD, яке дозволяє виконати числові розрахунки та побудувати часові діаграми у зручному вигляді.

Для розрахунків було задано такі початкові умови: температура повітря, тканини та бранш інструменту на початку $-20{ }^{\circ} \mathrm{C}$, густина тканини - 1035 кг/Mㄹ, питома теплоємність тканини 3400 Дж/кг $\cdot \mathrm{K}$, температура коагуляції - 57-60 C, коефіцієнти a=0.5, d=300, e=5.6, b=5, напруга живлення регулятора $\mathrm{U}_{0}=50 \mathrm{~B}$.

Коагуляція закінчується, коли максимальна миттєва потужність поточного періоду (другого та наступних) не перевищує 10 \% від першого.

На рисунках 5 - 7 зображено результати моделювання, а саме зміну опору тканини.

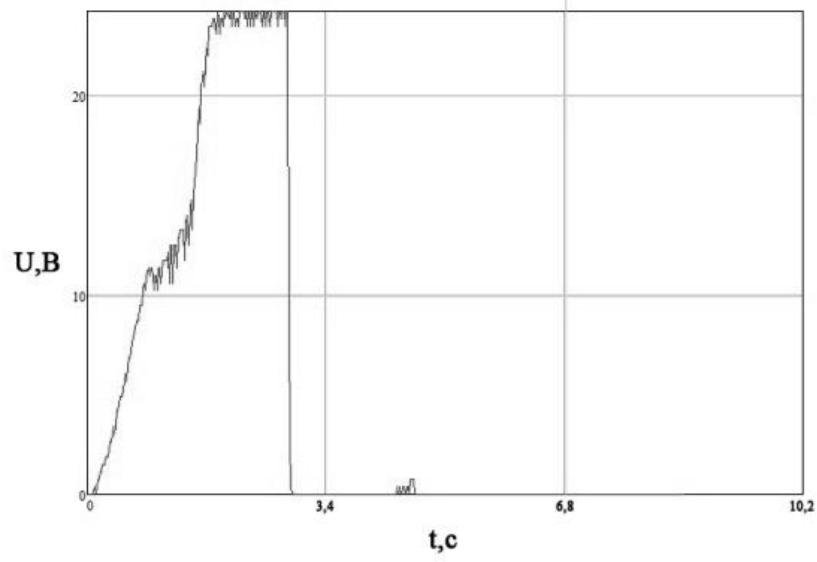

Рис. 5. Вхідна дія.

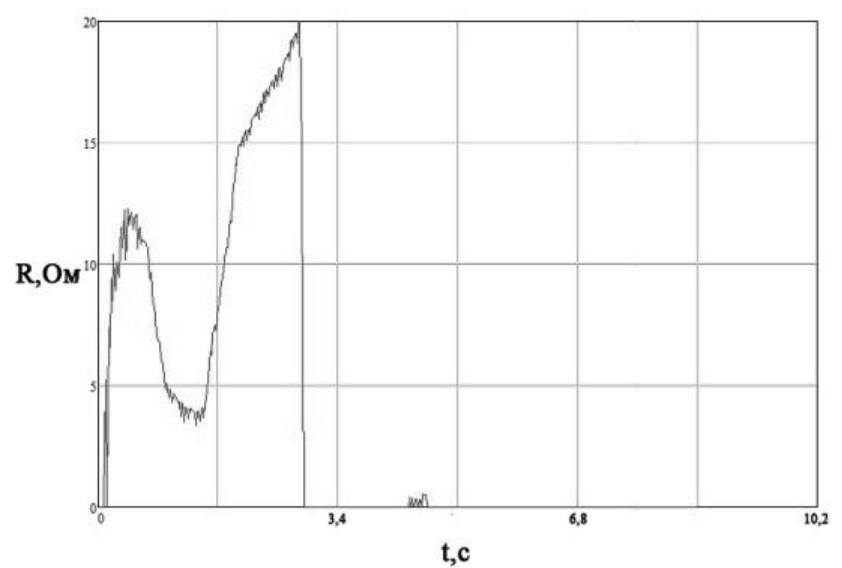

Рис. 6. Експериментальна залежність опору тканин від часу дії. 


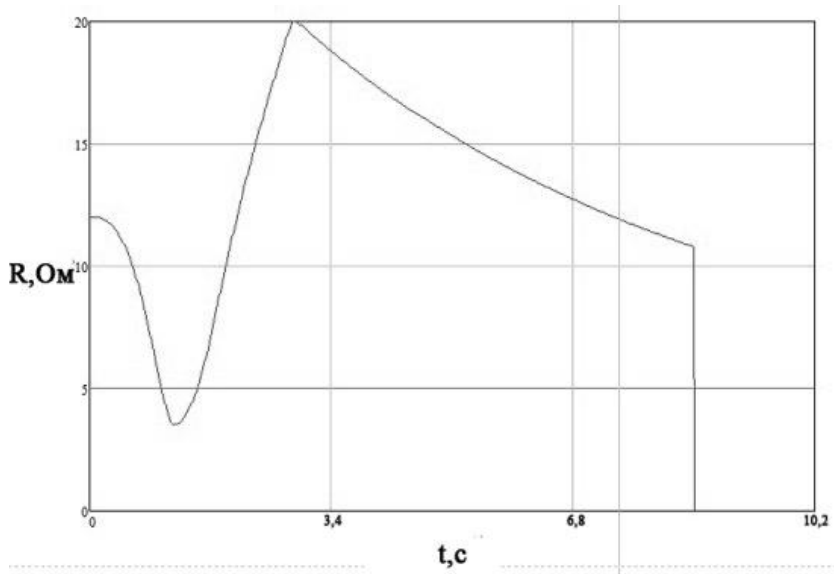

Рис. 7. Розрахункова залежність опору тканин від часу дії.

\section{СПИСОК ЛІТЕРАТУРИ}

1. Белов С. В. Исследование принципов электрохирургических воздействий и разработка научных основ проектирования аппаратов и устройств для высокочастотной электрохирургии : дис. ... доктора техн. наук : 05.11.17 / Белов Сергей Владимирович. - М., 2004. - 255 с.

2. Пат. ЕР1810633А2, МПК А61B 18/12. A system for controlling an electrosurgical generator having an impedance based control algorithm / Weinberg Craig, Leidich Kari ; filed 24.01.2007 ; published 25.07.2007.

3. Пат. US5472443 А США, МПК А61В 18/14, А61B 18/12, A61B 17/32. Electrosurgical apparatus employing constant voltage and methods of use / Jack C. Cordis; filed 17 Mar. 1994; published Dec. 5, 1995.

4. Пат. US6033399 США, МПК А61B 17/38. Electrosurgical generator with adaptive power control / David Lee Gines; filed Apr. 9, 1997; published Mar. 7, 2000.
Висновки. 1. Розроблені електромагнітні та теплові моделі дозволяють проводити розрахунок та корекцію алгоритмів і законів керування процесом ВЧ-зварювання тканин та перекриття судин як за сигналами зворотного зв'язку, так і результатами моделювання тканини, що дозволяє передбачити іï характер зміни з достатньою точністю (до $10 \%)$.

2. Результати є основою для вдосконалення існуючих та створення нових алгоритмів керування вихідною потужністю ЕХВА. Модель використовували для розробки алгоритму процесу біполярного з'єднання біологічних тканин, який враховує імпеданс тканини і максимальний час електрохірургічного впливу на тканини.

5. Пат. US6203541B1 США, MПК A61B 18/12. Automatic activation of electrosurgical generator bipolar output / David Keppel ; filed Apr. 23, 1999 ; published Mar. 20, 2001.

6. Пат. UA98035 Україна МПК А61В 17/04, А61В 18/12, A61N 1/18. Спосіб з'єднання зварюванням біологічних тканин людей та тварин / Кункін Д. Д., Перехрест В. В., Тодоренко В. А.; 01. 2006.

7. Feldman L. Fundamental Use of Surgical Energy (FUSE) / L. Feldman, P. Fuchshuber, D. B. Jones // Springer-Verlag New York, 2012.

8. Major R. H. History of medicine volumes I and II / R. H. Major, C. C. Thomas // Blackwell, 1954.

9. Schiavon M. Experimental evaluation of a new system for laser tissue welding applied on damaged lungs / M. Schiavon, G. Marulli, A. Zuin [et al.] // Interactive CardioVascular and Thoracic Surgery. - Oxford Journals. - 2013. - Vol. 16. - P. 577-582. 